\title{
JOURNAL
}

of Health Inequalities

\section{Limitations of cancer care in Central and South- Eastern Europe: results of the international conference organized by the Central European Cooperative Oncology Group (CECOG)}

Christiane Thallinger ${ }^{1,2}$, Ivica Belina ${ }^{3}$, Alina Comanescu4 ${ }^{4}$, Tanja Cufer ${ }^{5}$, Jacek Jassem6, Barbara Kiesewetter ${ }^{7}$, Lydia E. Markaroff ${ }^{8}$, Rene G. Ott ${ }^{9}$, Bartosz Polinski10, Radu Rasinar ${ }^{11}$, Alexander Rödiger ${ }^{12}$, Rafał Świerzewski13, Nils Wilking ${ }^{14}$, Christoph Zielinski2,15

\author{
'Department of Medicine I, Medical University Vienna, Vienna, Austria \\ ${ }^{2}$ Central European Cooperative Oncology Group (CECOG) \\ ${ }^{3}$ Coalition of Associations in Healthcare (Koalicija udruga u zdravstvu), Croatia \\ ${ }^{4}$ Community Health Association Romania \\ ${ }^{5}$ University Clinic Golnik, Medical Faculty Ljubljana, Slovenia \\ ${ }^{6}$ Medical University of Gdansk, Poland \\ ${ }^{7}$ Clinical Division of Oncology, Department of Medicine I, Medical University Vienna, Vienna, Austria \\ ${ }^{8}$ Fight Bladder Cancer, Oxfordshire, United Kingdom \\ ${ }^{9}$ AstraZeneca, Baar, Switzerland \\ ${ }^{10}$ Alivia Cancer Foundation, Poland \\ ${ }^{11}$ AstraZeneca, Bucharest, Romania \\ ${ }^{12}$ Merck GmbH, Switzerland \\ ${ }^{13}$ Foundation for Patients with Rare Diseases "COCARDA", Poland, and European Cancer Patient Coalition (ECPC) \\ ${ }^{14}$ Karolinska Institute, Stockholm, Sweden \\ ${ }^{15}$ Vienna Cancer Center, Vienna Hospital Association and Medical University Vienna, Vienna, Austria
}

\begin{abstract}
Profound disparities in cancer incidence and treatment outcomes, as well as accessibility of innovative EMA approved medications and technologies exist between Central, Eastern and South-Eastern (CEE) European countries and neighbouring Western European (WE) countries.

An international expert conference was held to discuss the current situation regarding the availability and affordability of innovative anti-cancer drugs in CEE, to define shortcomings in cancer care and to specify possible solutions to overcome the lack of access to anti-cancer medications in the region. Consequently, all experts agreed that national prevention programs targeting smoking, obesity and alcohol consumption, and cancer screening programmes should be widely implemented in CEE countries. Considering limited healthcare resources in most CEE countries, an efficient allocation in a more structured way with clear cancer patient pathways to contain costs is needed. Also, more rapid reimbursement decisions and introduction of novel drugs in routine clinical practice, along with better access to clinical trials, are needed. There was consensus that higher investments into cancer care and more organized, value-oriented application of novel diagnostic and treatment approaches are necessary.

Furthermore, it was suggested that patient organisations should be more involved in cancer research, clinical research and reimbursement processes. Postulated were also higher investments into cancer care and more organized, value-oriented application of novel diagnostic and treatment approaches.
\end{abstract}

KEY WORDS: cancer care, inequality, access, cancer control plans. 


\section{INTRODUCTION}

Several pan-European studies on cancer outcomes report profound disparities in cancer care, survival and cancer-driven mortality across Europe, which have their roots in inequities in general wealth and health between European countries [1-3]. They are a consequence of highly different health care systems, with disparate populations and wide variations in technological, human and financial resources that are available for the care of cancer patients in different countries.

The increasing cancer burden that we experience in Europe will have a profound impact not only on patients and their families, but will also be a significant challenge for our healthcare systems and for the future economic competitiveness of Europe. While the simplest solution would be to increase spending on health in general, and cancer care in particular, it has been acknowledged that the problem is not simply about spending, but about spending wisely [4]. The problems lie not only in limitations in access to treatment, but also in deficits of prevention, screening and early diagnosis. Hence, cancer control policies have to be aligned with public health strategies related to disease prevention [5]. In addition, there has been an unprecedented wave of innovations in cancer treatment in the past few years, which may have a considerable budget impact and require new approaches to ensure timely patient access [6].

Against this background, the Central European Cooperative Oncology Group (CECOG) initiated a high-profile meeting with experts from Central and South-Eastern Europe to discuss the current situation of cancer care with the aim of developing joint approaches to tackle inequities in cancer care and to improve cancer patients' access to early diagnosis, followed by high-quality treatment with value-based medicines and technologies in the region.

\section{THE STATUS QUO IN CANCER CARE IN CENTRAL AND SOUTH-EASTERN EUROPE

Europe accounts for $9 \%$ of the world's population but its share of global cancer cases and cancer deaths is about $25 \%$ [1]. Within the past three decades, cancer incidence has increased by approximately $30 \%$ across Europe and will continue to rise: In 2018, there were close to 4.23 million new cases of cancer in Europe, and this number is predicted to rise by almost a quarter to 5.2 million by $2040[7,8]$.

Studies show a North West to South East gradient of increasing incidence and mortality rates of tobacco-related and screening-detectable cancers, with a lack of decline in overall cancer mortality in Southeast European countries (SEE) $[3,9]$. Data from EUROCARE-5 suggest less effective care as reason for the higher risk of cancer death in CEE, and worse stage-specific survival compared to the rest of Europe due to a restricted allocation of resources to healthcare (Table 1) [10-14].
Several causes of this discrepancy between Central, Eastern and South-Eastern Europe (CEE) and Western Europe (WE) have been proposed, including differences in distribution of risk factors, lack of primary prevention, lower access to cancer screening, later stage at diagnosis, more deadly cancer types, lower access to quality care, fewer available treatment options, lower availability of novel drugs, lack of access to specific equipment such as radiotherapy and to trained oncology specialists, lack of national cancer plans, and absence of comprehensive cancer registries $[3,15]$.

\section{MAJOR GAPS IN HEALTHCARE EXPENDITURES AND COST OF CANCER ACROSS EUROPE}

The distinct mortality trends in CEE and WE have been associated with large differences in health care budgets and the absolute investment in cancer care (Table 1) $[16-20]$. Health expenditure per capita strongly correlates with the gross domestic product (GDP) per capita and with the percentage of GDP allocated to healthcare [19]. While the population of WE are approximately four times larger than that of CEE, its GDP exceeds that of CEE more than 10-fold [19] (Fig. 1).

Similarly, a correlation between lower expenditure on oncology drugs and mortality-to-incidence ratio in CEE compared to WE have been shown in a cross-sectional analysis [3] (Fig. 2). While the percentage of GDP spent on oncology drugs was similar in both regions, the absolute expenditures on drugs per capita and per cancer case in CEE countries were 2.5 times less than in WE countries.

For radiotherapy, investments have been uneven across Europe and many countries face serious limitations. Whereas the Nordic countries, Belgium, the Netherlands, and Switzerland are well equipped with external beam machines, most countries in Central and South-Eastern Europe face substantial shortages and the urgent need to expand and modernise their equipment [21]. In many cases, the significant limitations in radiotherapy resources result in waiting lists, delays in initiation of radiotherapy and reduced effectiveness of radiation treatment [21]. It is estimated that at least a quarter of patients in Europe eligible for radiotherapy currently do not receive it [21]. At the same time, the demand for radiotherapy in the region is expected to grow by $16 \%$ by 2025 [22], requiring substantial additional investments.

However, spending is not the only factor explaining cancer survival differences. An analysis of results from published EUROCARE high-resolution studies on breast, colorectal, and prostate cancer found that countries with similar high or low total national health expenditures have different survival rates [23]. Ades et al. showed a strong correlation between the efficiency of a country's health policy and health expenditure and the breast cancer mortality/ incidence ratio and that both variables are also directly associated with the speed of drug reimbursement [24]. 
TABLE 1. Expenditures on health, cancer care, 5-year survival rates and death rates across Central-Eastern and South-Eastern countries as compared to Austria

\begin{tabular}{|c|c|c|c|c|}
\hline Country & $\begin{array}{c}\text { Total health } \\
\text { expenditure as \% } \\
\text { of GDP* }\end{array}$ & $\begin{array}{c}\text { Cancer share } \\
\text { of health } \\
\text { expenditure }\end{array}$ & $\begin{array}{c}\text { 5-year relative } \\
\text { survival } \\
\text { (all cancers) }\end{array}$ & $\begin{array}{l}\text { Standardised death } \\
\text { rates per } 100,000 \\
\text { inhabitants }\end{array}$ \\
\hline Austria & 10.8 & 6.8 & 59.43 & 243.4 \\
\hline Bulgaria & 4.7 & 6.8 & 47.79 & 241.9 \\
\hline Croatia & 6.9 & 6.9 & 53.42 & 335.7 \\
\hline Czech Republic & 7.5 & 5.4 & 46.40 & 278.8 \\
\hline Estonia & 6.5 & 5.8 & 39.92 & 299.1 \\
\hline Hungary & $7.2^{+}$ & - & - & 345.9 \\
\hline Latvia & 5.5 & 6.2 & 47.75 & 293.7 \\
\hline Lithuania & 6.5 & 6.2 & 48.96 & 285.5 \\
\hline Poland & 6.9 & 6.5 & 46.47 & 304.5 \\
\hline Romania & 4.1 & 6.8 & - & 275.3 \\
\hline Slovakia & 7.9 & 6.2 & 51.94 & 320.1 \\
\hline Slovenia & 8.5 & 6.7 & 41.96 & 310.5 \\
\hline Northern Europe & - & 58.24 & & \\
\hline Central Europe & - & 61.30 & & \\
\hline Eastern Europe & - & 50.91 & & \\
\hline Southern Europe & - & 58.91 & & \\
\hline European average & 9.4 & 50.34 & & \\
\hline
\end{tabular}

"latest available data; source [13], ," data from 2014; source [2], "* data from 2000-2007; source [14], " source [11]," data from 2015; source [12]

\section{OUT-OF-POCKET PAYMENTS FOR HEALTH SERVICES}

A major financial burden for patients in CEE countries are out-of-pocket payments for health services [2527]. Out-of-pocket payments are higher in countries where important health services are not included in the public benefit basket and/or cost-sharing of public payers is limited for some services. $18 \%$ of all health spending in the EU is borne directly by private households, ranging from $10 \%$ in France, Luxembourg or the Neth-

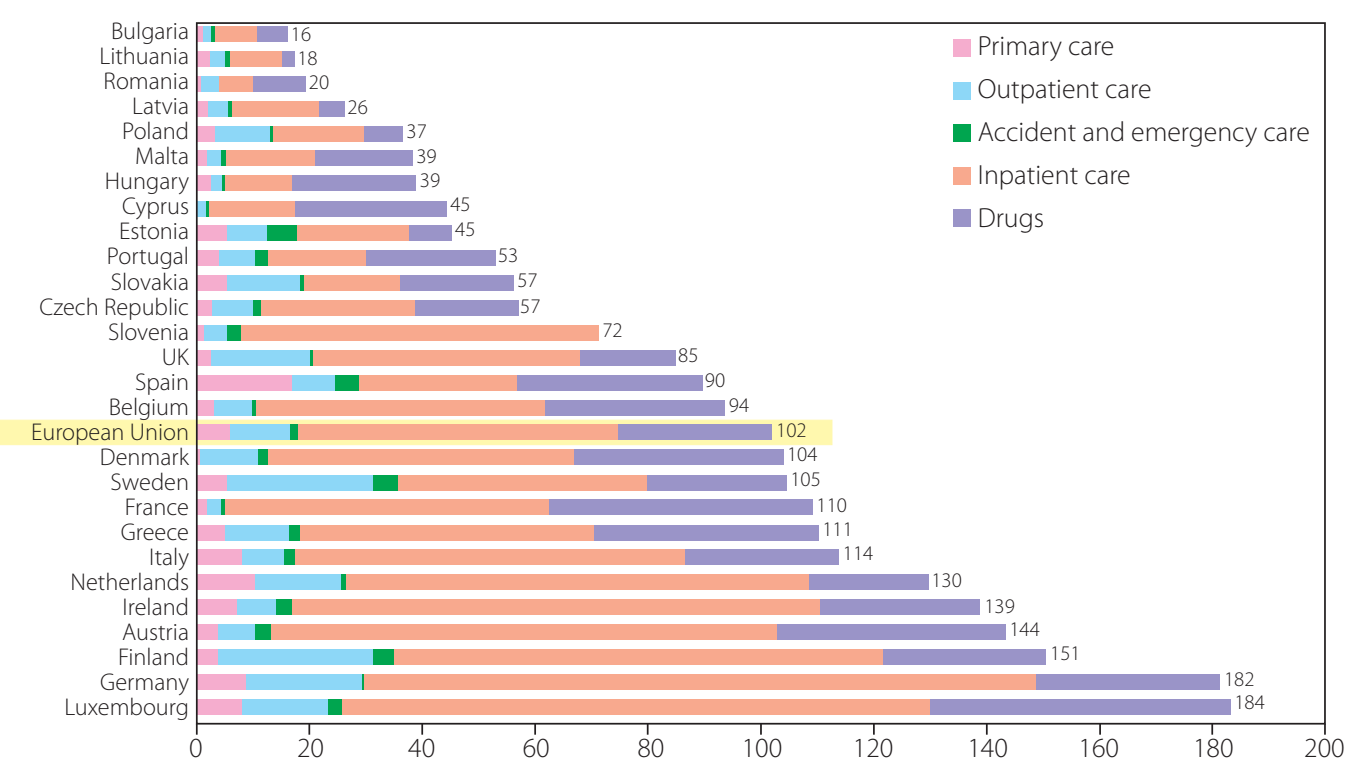

FIG. 1. Health-care costs of cancer per person in EU countries in 2009 by health-care service category. Data not adjusted for price differentials [84] 


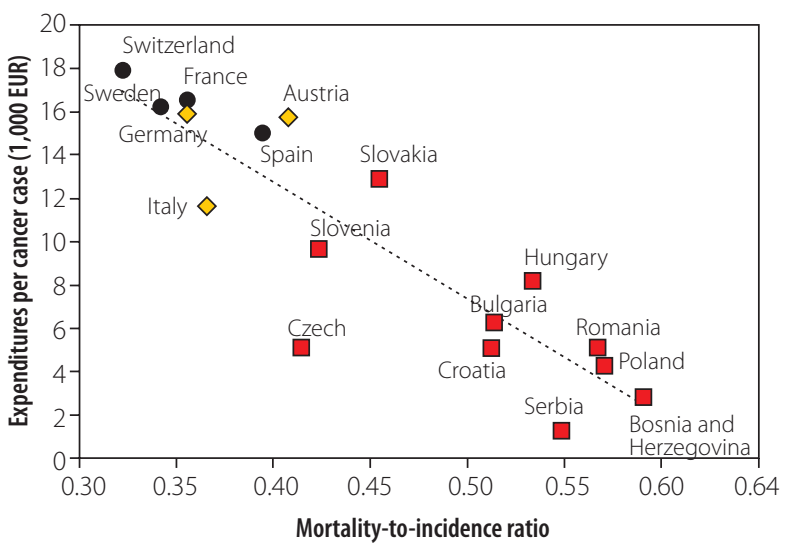

FIG. 2. Correlation of annual expenditures per new cancer case for antineoplastic drugs (ATC L01 class) and mortality-to-incidence ratio (2015, all cancers). Red squares represent Central and Eastern Europe countries, yellow rhombuses represent neighbouring Western Europe (WE) countries, and blue circles represent other WE countries [3]

erlands to over $40 \%$ in Bulgaria, Latvia and Cyprus (see supplement, Fig. S1).

\section{SHORTAGES, RESTRICTIONS AND DELAYS OF ACCESS TO DIAGNOSTICS AND TREATMENTS IN EUROPE}

Non-small-cell lung cancer (NSCLC) molecular testing - a paradigmatic example for targeted treatment

Lung cancer is the leading cause of cancer mortality worldwide [7] and also the most common cancer in CEE countries [8]. Since lung cancer consists of more than 50 histomorphological subtypes, diagnosis requires a comprehensive approach analysing anatomical, morphological and molecular features of the tumour to determine the most appropriate treatment option $[28,29]$.

Non-small-cell lung cancer (NSCLC) accounts for $80-85 \%$ of all lung cancers [29]. In 2016, a questionnaire-survey about molecular testing and NSCLC management in nine CEE countries (Bulgaria, Croatia, Czech Republic, Hungary, Israel, Poland, Slovakia, Slovenia, Turkey) showed that molecular testing of NSCLC samples is well established in these countries and most follow national or international guidelines but limited reimbursement significantly hampers molecular testing in general and reflex testing in particular [30].

These results were confirmed in a similar survey, initiated by CECOG in 2016 as a two-step-survey on the availability of different diagnostic procedures of NSCLC and the reimbursement landscape of drugs for NSCLC in CEE countries (Austria, Bulgaria, Croatia, Czech Republic, Hungary, Poland, Romania, Serbia, Slovakia and Slovenia) $[29,30]$. In the first step, wide variations in both availability and reimbursement of diagnostic tests between CEE countries were observed. Not only is "reflex" testing often substituted by analyses performed only "on demand," but reimbursement of assessments varies widely between unavailability and payments by the health care system or even pharmaceutical companies. Analyses of reimbursement of modern drugs for the treatment of lung cancer in CEE showed also a highly divergent picture between various countries [31].

\section{Anticancer drugs}

The past two decades have seen major advances in diagnostic procedures and treatment technologies with the potential to save, improve and extend the lives of millions of people with cancer. But these improvements are associated with high expenditures that threaten the sustainability of health care systems globally. An economic study found that the average launch price of anticancer drugs, adjusted for inflation and health benefits (survival), increased by $10 \%$ annually or an average of $\$ 8,500$ per year from 1995 to 2013 [32].

Several studies reported high discrepancies in the availability of innovative drugs to patients that most needed them [19, 24, 26, 33]. For example, huge delays in reimbursement across Europe have been shown in the case of the humanized anti-HER 2 monoclonal antibody trastuzumab in the adjuvant and metastatic setting with marked differences in time to approval/ reimbursement between WE and CEE countries of up to 12 years $[33,34]$.

This is in line with the second step of the above mentioned CECOG survey, which found that time from registration to reimbursement of targeted treatments like tyrosine kinase inhibitors or immune checkpoint inhibitors in NSCLC is usually long and could last one year or more [31].

Particularly in Eastern European countries with lower levels of economic development, the lack of availability is largely related to novel targeted agents, which gained market approval only in the past 10 years and are associated with high out-of-pocket costs [26]. In contrast, most of the cancer medications included in the updated version of the WHO model essential medicines list (EML) are usually available with no out-of-pocket cost to patients but shortages also affect EML medicines, e.g. tamoxifen and cisplatin, largely due to manufacturing and distribution issues [26]. In 2018, the European Association of Hospital Pharmacists (EAHP) found that shortages are getting worse compared to the results of the 2014 and 2017 surveys [35, 36]. Medicines' shortages in hospitals often last for weeks or even months, cause delay and cancellations in care, result in medication errors and, finally, in suboptimal patient care.

Besides the budget impact of innovative medicines, certain pricing and reimbursement policies interfere with timely patient access, in particular price benchmarking (external reference pricing) and parallel trade [37]. Delays imposed by health technology assessment (HTA) procedures and price negotiations, as well as characteristics 
of health systems with low administrative capacities or with inefficiencies also undermine timely patient access to innovative treatments [38]. In addition to the discrepancies within European countries, there are also considerable regional differences across member states when it comes to spending on oncology drugs [39].

\section{RADIOTHERAPY}

Radiotherapy (RT) plays an important role in the curative and palliative setting next to surgery and chemotherapy with a general utilization proportion of $\sim 50 \%$ [40]. To optimize the quality and availability of RT, guidelines have been proposed in 2005 by the European Society for Radiotherapy \& Oncology (ESTRO) and in 2010 by the International Atomic Energy Agency (IAEA) [41, 42]. Nonetheless, at least one in four people needing radiotherapy does not receive it [21].

A report on actual and optimal RT capacity in 33 European countries described huge availability deficiencies of equipment, primarily teletherapy units [43]. Lack of qualified manpower for optimal delivery of radiotherapy services exacerbates the problem [44].

In 2012, projected needs of total RT capacity for 2020 estimate a general deficit of $25.6 \%$ with regard to RT units $(n=1698)$ and of $18.3 \%$ for radiation oncologists $(n=2429)$ compared with current guidelines [45]. Based on the expected proportion of new cancer patients that will require at least one course of radiotherapy by 2025 , an increase in the number of RT treatment courses of $16 \%$ was estimated with variations across European countries from less than 5\% to more than $30 \%$ [22].

These data point to significant shortages of both equipment and qualified manpower with a lack of strategic attention to RT at the policy level. Globally, more that $40 \%$ of high-income countries have national cancer control or general health care plans that do not address RT as an option [46]. In many European countries RT is not even included in the general oncology curriculum [47].

\section{LACK OF PRIMARY PREVENTION AND SCREENING PROGRAMS IN CENTRAL AND SOUTH-EASTERN EUROPE}

Around $40 \%$ of cancer cases are caused by potentially modifiable cancer risk factors, including tobacco use, high alcohol intake, poor diet, lack of physical activity, obesity as well as infections and environmental factors, which can be prevented through lifestyle changes and actions at the individual and societal levels [48-52].

While primary prevention is the most cost-effective long-term public health strategy in cancer control early detection and diagnosis of cancer through population-based screening programmes should be prioritized since treatment at early cancer stages is generally more effective, less complex and less expensive than in the advanced setting [53-55]. In 2003, the EU Council pub- lished a series of recommendations urging Member States to introduce or scale up breast, cervical and colorectal cancer screening through systematic population-based approaches with quality assurance at all levels [56].

While the first report, prepared by the International Agency for Research on Cancer (IARC), highlighted the adoption of the Council recommendations it also concluded that the number of individuals having access to population-based screening in the year 2007 was much lower than the desired level $[57,58]$. According to the second report (2017), substantial improvement in screening efforts across most of the EU Member States has been achieve in 2016 with the exception of Bulgaria, Greece and the Slovak Republic [59]. On-going rollout was reported for Slovenia and Lithuania. Romania had a small-scale pilot project on-going in 2016; thus, the majority of the target population was subjected to non-population-based screening. Bulgaria completed a pilot project ("Stop and Get Screened") in 2014 to provide breast, cervical and colorectal cancer screening using a population-based approach, though there was no scaling up.

Rollout of population-based cervical cancer screening programmes was complete in 4 CEE countries (Slovenia, Poland, Latvia and Estonia) whereas rollout was on-going in another six (Czech Republic, Hungary, Romania, Croatia, Lithuania).

Population-based colorectal cancer screening programmes were being rolled out in Slovenia, Czech Republic and Croatia, with rollout on-going in Poland and Lithuania. While Hungary and Estonia were piloting population-based colorectal cancer screening programmes, Slovakia, Romania and Bulgaria had no such programmes [57].

The European expert group EUPS recommended a European lung cancer screening policy and the implementation of a lung cancer screening program by 2019/2020 [60]. Currently several national screening programmes are established in Europe ranging from the Nordic countries, to Switzerland and Poland [6163]. While Poland and Hungary are piloting lung cancer screening programmes in the Central and Southern Europe region, no programmes have been implemented or published in the other countries $[63,64]$.

With regard to invitation coverage, all screening programmes showed a high variation across the EU, ranging from $0.2-111 \%$ for breast cancer, $7.6-105 \%$ for cervical cancer and $1.8-127 \%$ for colorectal cancer in the target populations [58].

To improve implementation, monitoring and evaluation of breast, cervical and colorectal cancer screening programmes, the European project EUROCOURSE called for a collaboration between cancer registries and screening programmes since monitoring and evaluation are essential to quality assurance of population-based cancer screening programmes [65]. 


\section{SCARCITY OF NATIONAL CANCER REGISTRIES}

The earliest population-based cancer registries (PCR) in Europe have been established more than 70 years ago (e.g. Denmark 1942; Slovenia 1950; Sweden and Norway 1951; Finland 1952) but still one third of the European population lacks quality cancer registration [66-68].

Currently, nearly 200 PCR are members of the European Network of Cancer Registries (ENCR) covering about $60 \%$ of the European population, with an increasing trend [68-71]. High quality registration of 10-60\% of the population is available in France, Germany, Italy, Poland, Serbia, Switzerland and Spain, which all have national plans and legislation to reach complete coverage [1,71]. For nine European countries (Albania, Bosnia-Herzegovina, Northern Macedonia, Greece, Luxembourg, Hungary, Romania, Portugal, Moldova, Montenegro, Serbia) the latest national incidence data publicly available for 2014/15 represented only estimates, which were calculated based on data available from partial registration and registries in neighbouring countries [1].

To reduce the disparities in terms of CRs population coverage, data quality, and data output across Europe and to reach a harmonised, collaborative, and effective system of cancer surveillance in Europe, engagement of all stakeholders on national and pan-European levels are needed $[68,71]$.

\section{CLOSING THE GAP OF CANCER CARE IN EUROPE - INITIATIVES AND CROSS- COUNTRY ACTIONS}

Initiatives by the European Union

In 1985, the Heads of State and Government of the then twelve Member States of the European Community decided to launch the first "Europe Against Cancer" (EAC) programme which became operational in 1987. This initiative of the European Commission (EC) was the first of many to follow with the aim to reduce the burden of cancer in the EU, often in close collaboration with the WHO and the IARC (see Supplement, Table S1) $[56,72,73]$.

\section{INITIATIVES BY MEDICAL SOCIETIES, HEALTH-RELATED ORGANISATIONS AND PATIENT ADVOCACY GROUPS}

To reduce cancer mortality in Europe, medical societies and health-related organisations as well as patient advocacy groups regularly engage in public policy and European affairs (Table 2). The most prolific organisations are the European Society for Medical Oncology (ESMO) [74, 75], the WHO Regional Office for Europe (WHO/Europe) [54, 76, 77], the European CanCer organisation (ECCO) $[78,79]$ as well as the European Cancer Patient Coalition (ECPC) [80-83] and the All. Can group [84]. The International Atomic Energy Agency (IAEA) [85-89] has implemented extensive capaci-

TABLE 2. Main initiatives by medical societies and health-related organisations

\begin{tabular}{|c|c|c|}
\hline Acronym & Society/Organisation & Aims \\
\hline $\begin{array}{l}\text { ESMO } \\
{[74,75]}\end{array}$ & $\begin{array}{l}\text { European Society for Medical } \\
\text { Oncology }\end{array}$ & $\begin{array}{l}\text { To reduce healthcare inequalities } \\
\text { To publish cancer policy briefings and statements (e.g. in case } \\
\text { of the new EU Clinical Trials Regulation) } \\
\text { To advocate for EU recognition of the specialty of medical } \\
\text { oncology } \\
\text { To collaborate with EU Presidencies }\end{array}$ \\
\hline $\begin{array}{l}\text { WHO/Europe } \\
{[76,77]}\end{array}$ & $\begin{array}{l}\text { World Health Organisation } \\
\text { Regional Office for Europe }\end{array}$ & $\begin{array}{l}\text { To coordinate and conduct research on causes and develop } \\
\text { scientific strategies for cancer prevention and control, e.g. } \\
\text { WHO Framework Convention on Tobacco Control, Action Plan } \\
\text { for the Prevention and Control of Noncommunicable Diseases } \\
\text { in the WHO European Region 2016-2025 }\end{array}$ \\
\hline $\begin{array}{l}\text { IAEA } \\
{[86-90]}\end{array}$ & $\begin{array}{l}\text { International Atomic Energy } \\
\text { Agency }\end{array}$ & $\begin{array}{l}\text { To enhance capacity in Member States to safely and } \\
\text { effectively detect and treat cancer using nuclear techniques: } \\
\text { Programme of Action for Cancer Therapy (PACT), Technical } \\
\text { Cooperation projects in human health, Coordinated Research } \\
\text { Projects (CRPs) in human health/radiotherapy worldwide }\end{array}$ \\
\hline $\begin{array}{l}\text { ECCO } \\
{[79,80]}\end{array}$ & European CanCer Organisation & $\begin{array}{l}\text { To improve outcomes for all cancer patients in Europe } \\
\text { through multidisciplinarity } \\
\text { To improve access to innovation } \\
\text { To address disparities in cancer outcomes across Europe } \\
\text { To address financial discrimination encountered by cancer } \\
\text { patients } \\
\text { To promote cancer research at an European level }\end{array}$ \\
\hline
\end{tabular}


ty building activities in all of its Member States in the region provided through their Technical Cooperation (TC) programme in cancer and radiation medicine. The IAEA and the European Society for Radiotherapy and Oncology (ESTRO) collaborate and provide sponsored training courses to increase the efficiency of technical cooperation activities, and facilitate networking among Member States, professional associations and partner organizations, such as the World Health Organization (WHO). The All.Can group comprises leading representatives from patient organisations, policymakers, healthcare professionals, research and industry from across Europe and Canada and was set up in 2016 to optimise the efficiency of cancer care by focusing on improving outcomes for cancer patients [84].

\section{NATIONAL CANCER CONTROL PROGRAMMES}

The concept for National Cancer Control Programmes (NCCP) was developed by the WHO in 1995 to provide the framework for national policies on cancer control with the aim of reducing cancer morbidity and mortality, and improving the quality of life of cancer patients [90, 91].

In order to support national efforts in preparation of services and actions related to cancer control, the EU has initiated the "European Guide for Quality National Cancer Control Programmes" to serve as a guide to Member States [92]. The IAEA also offers its Member States a planning tool, known as an integrated review of comprehensive cancer control needs and capacities (imPACT) [93]. This review is being organized at the request of the national authorities, i.e. the Ministry of Health, and is conducted in close collaboration with relevant national and international health authorities, such as WHO and the International Agency for Research on Cancer (IARC). It assesses the status of national capacities for the implementation of cancer control plans and the readiness to establish long-term radiation medicine infrastructure projects [93]. Since 2005, over 100 IAEA Member States have benefited from imPACT reviews, including several CEE countries, i.e. Albania, Serbia, Montenegro, Moldova, Armenia, Romania, Tajikistan, Uzbekistan, Georgia, Croatia, Kyrgyzstan, Bosnia-Herzegovina, Belarus, Kazakhstan, Ukraine and North Macedonia.

\section{IMPROVING PATIENT CARE PATHWAYS}

Delays in diagnosing symptomatic cancer, leading to more advanced stage at diagnosis are one of the factors contributing to poor cancer outcomes [94]. Intervals between referral for suspicion of cancer, confirmation of diagnosis and beginning of treatment are indicators of quality in cancer care [95]. Systematic efforts to enhance the delivery of cancer services have been introduced in several health systems in Europe, such as the UK, Sweden, Denmark and Hungary. All these programmes aim to reduce waiting times via special care pathways, specifying time frames for different diagnostic steps [96-101]. The psychological burden faced by Eastern European cancer patients and their carers is addressed by providing access to psycho-oncological therapy. Psycho-oncology and palliative care should be included in the national cancer guidelines.

\section{ACCESS TO TREATMENT AND VALUE ASSESSMENT}

Marketing authorisation by the European Medicines Agency (EMA) is generally based on a benefit-risk assessment, in which a benefit clearly outweighs the risks of a drug. To satisfy unmet medical demands of patients or overall public health priorities, EMA has introduced the conditional approval pathway that allows marketing authorisations to be granted on the basis of limited evidence [102]. However, reducing premarketing development procedures may increase the risk of approving ineffective and/or unsafe drugs [103, 104].

Since the trend towards faster access to medicines with uncertain benefit is increasing rather than declining, systematic and transparent post-approval monitoring mechanisms are of high relevance to assure a clinically relevant patient benefit [104]. Countries like the UK or France have established mechanisms such as the Cancer Drugs Fund (CDF) or the temporary authorisation for use (ATU; authorisation temporaire d' utilisation), which allow early access while evidence is further developed [105, 106]. Other countries, like Belgium, have developed a longer-term medicines strategy, securing timely access while setting financial resources aside to finance innovation ("Pact of the Future").

To stratify the potential clinical benefit that may be anticipated from a novel anticancer treatment, ESMO developed the Magnitude of Clinical Benefit Scale (ESMO-MCBS), a standardized, generic, validated approach to stratify the magnitude of clinical benefit from anticancer therapies $[107,108]$. The costs of treatments are not integrated in view of significant heterogeneity across Europe. The ESMO-MCBS is an important first step to the critical public policy issue of value in cancer care, supports treatment decisions based on the clinical benefit to be expected from a novel approach and might also support decision-making within socioeconomic questions.

\section{FUNDING FOR CANCER MEDICINES - A COLLABORATIVE POLICY-MIX NEEDED}

Efficient procurement of medicines means that products of good quality are available at affordable prices on a sustainable basis and at the right time [109]. In most European countries, citizens benefit from comprehensive coverage of healthcare costs and a major part of spending on medicines comes from public programmes [110]. However, there is considerable variation in public 
funding on medicines between countries, especially with regard to high-priced innovative medicines.

To achieve affordable access while securing sufficient incentives for future innovation various strategies have been proposed, such as cross-country collaboration, in-market competition, tiered or differential pricing or managed entry agreements (MEAs) $[35,55,109$, 111-113]. The European Federation of Pharmaceutical Industries and Associations (EFPIA) has put forward five guiding principles for cross-border collaboration, including relevance for patients, acceleration of access, similarity of collaborating countries, voluntariness and the protection of commercial information [114].

Several EU-wide as well as more localized initiatives have been established and reflect the growing interest in voluntary collaboration on access to new medicines and other medical products $[56,111]$. Although joint procurement collaboration seems promising, the evidence is still missing in terms of whether such deals are actually working to reach lower prices and broadened access to medicine in Europe [115].

Many countries increasingly use managed entry agreements (MEAs), i.e. either financial agreements to obtain discounts on list prices or performance-based agreements, which link coverage conditions or prices to health outcomes in real life, either on each patient or on the whole patient population $[111,116]$. The type of MEA for a single product/indication may vary across countries [117]. Although MEAs, in particular outcomes-based agreements, may involve some complexities - data infrastructure, time to negotiate and administer agreements - they allow for timely access while ensuring predictable budget impact as the CDF example in the UK shows [118].

\section{CONCLUSIONS OF THE CECOG MEETING TO IMPROVE ACCESS TO BETTER CANCER CARE IN CEE COUNTRIES}

Disparities in cancer care between Western/Central Europe and Eastern/South-Eastern Europe are highly related to differences of the general economic situation as well as the organisation of the respective health care systems.

There is not only a discrepancy in access to novel cancer medicines and upgraded technologies, but also with regard to the quality of cancer care, especially concerning prevention programmes, supportive and palliative care as well as cancer care provision.

The data presented here indicate that solutions to these disparities in outcome might mainly be reached by increasing expenditures on health in general, and cancer services in particular, in countries with survival figures significantly below the average [16]. If disparities are to be eliminated, it is not enough to concentrate all attention on one area such as drug costs as part of general country-specific health care systems. To this end, a systems-based approach is required which engages all involved stakeholders - patients, physicians and politicians. Good examples are the CDF in the UK or the "Pact of the Future" in Belgium.

Accordingly, the panel discussions of the CECOG meeting included suggestions for improvement of oncology care in CEE countries:

- In light of limited healthcare resources in most CEE countries, an efficient allocation in a more structured cancer patient management with less inpatient/ hospital-based care and more ambulatory and day care treatment to contain costs should be pursued to reduce costs and to improve patients' quality of life.

- In countries with substantial out-of-pocket payments health system financing needs to be revisited.

- Access is a joint responsibility. All stakeholders should work together on an access to cancer care strategy.

- In the majority of CEE countries more rapid reimbursement decisions and introduction of novel drugs in routine clinical practice, along with better access to clinical trials, are needed. To achieve this, higher investments into cancer care and more organized, value-oriented application of novel diagnostic and treatment approaches are necessary.

- The implementation, as well as the up-to-date revision of national cancer control plans must involve all stakeholders - policy makers, academia, patients.

- With regard to epidemiologic data on preventable cancer risk factors, CEE countries should widely implement national prevention programs targeting tobacco smoking, obesity, HPV vaccination and alcohol consumption.

- Patients advocacy groups should be much more involved in cancer research, approval processes as well as decision-making with regard to prioritise cancer treatment reimbursement.

- Screening programmes should be universally available, implemented and attract as much persons as possible.

- Molecular cancer testing is mostly available; however, more structured and sustainable policies of molecular testing and reimbursement are needed to ensure testing to all patients in the majority of countries.

- Population-based cancer registries containing also information on treatment are highly needed.

- "Clinical benefit" from and "value" of treatment modalities that include quality and consistency of evidence for effectiveness, toxicity, and cost of cancer medicines should be considered.

- Pressure should be put on registration agencies (FDA, EMA) to use a criterion of value for approval such as the ESMO-Magnitude of Clinical Benefit Scale (ESMOMCBS) rather than statistical significance of an outcome measure. Simultaneously, it should be considered whether treatments with a low clinical benefit should not be abandoned in favour of more effective ones. 
- In many countries social education is needed to change the attitude of the society towards cancer ("cancer = death"), and to advocate that cancer is to a large part a preventable chronic disease.

- Patients advocacy groups should be much more involved in clinical trials development on the regional level, and increasing access to clinical trials, in collaboration with the pharmaceutical industry, academia and healthcare professionals.

- Every country of the CEE region should develop a clear cancer patient pathway and record treatment outcomes. This should be a joint endeavour of healthcare professionals and patient advocacy groups. The final outcome should be the development and implementation of national systems of comprehensive cancer care from primary prevention to palliative care.

\section{DISCLOSURE}

The authors report no conflict of interest.

\section{References}

1. Ferlay J, Colombet M, Soerjomataram I, et al. Cancer incidence and mortality patterns in Europe: estimates for 40 countries and 25 major cancers in 2018. Eur J Cancer 2018; 103: 356-387.

2. Jönsson B, Hofmarcher T, Lindgren P, Wilking N. The cost and burden of cancer in the European Union 1995-2014. Eur J Cancer 2016; 66: 162-70.

3. Vrdoljak E, Bodoky G, Jassem J, et al. Expenditures on oncology drugs and cancer mortality-to-incidence ratio in Central and Eastern Europe. Oncologist 2019; 24 (1): e30-e37.

4. Uyl-de Groot CA, de Vries EGE, Verweij J, Sullivan R. Dispelling the myths around cancer care delivery: It's not all about costs. J Cancer Policy 2014; 2 (1): 22-29.

5. Wild CP, Espina C, Bauld L, et al. Cancer Prevention Europe. Mol Oncol 2019; 13 (3): 528-534.

6. IQVIA Institute for Human Data Science. Global Oncology Trends 2018. Innovation, Expansion and Disruption. Parsippany/New Jersey, USA. Available from: https://www.iqvia. com/institute/reports/global-oncology-trends-2018 (accessed: 11 June 2020).

7. Bray F, Sankila R, Ferlay J, Parkin DM. Estimates of cancer incidence and mortality in Europe in 1995. Eur J Cancer 2002; 38 (1): 99-166.

8. Ferlay J, Steliarova-Foucher E, Lortet-Tieulent J, et al. Cancer incidence and mortality patterns in Europe: estimates for 40 countries in 2012. Eur J Cancer 2013; 49 (6): 1374-1403.

9. Znaor A, van den Hurk C, Primic-Zakelj M, et al. Cancer incidence and mortality patterns in South Eastern Europe in the last decade: gaps persist compared with the rest of Europe. Eur J Cancer 2013; 49 (7): 1683-1691.

10. Minicozzi P, Walsh PM, Sánchez MJ, et al; Is low survival for cancer in Eastern Europe due principally to late stage at diagnosis? Eur J Cancer 2018; 93: 127-137.

11. OECD/European Observatory on Health Systems and Policies, Hungary: Country Health Profile 2017, State of Health in the EU. OECD Publishing, Paris/European Observatory on Health
Systems and Policies, Brussels 2017. Available from: https:// www.oecd.org/publications/hungary-country-health-profile2017-9789264283411-en.htm (accessed: 11 June 2020).

12. Eurostat statistics explained. Cancer statistics. Available from: https://ec.europa.eu/eurostat/statistics-explained/index.php/ Cancer_statistics\#Deaths_from_cancer (accessed: 11 June 2020).

13. WHO/ European Health Information Gateway. Available from: https://gateway.euro.who.int (accessed: 11 June 2020).

14. ECIS - European Cancer Information System. Available from: https://ecis.jrc.ec.europa.eu (accessed: 11 June 2020).

15. Forman D, Bauld L, Bonanni B, et al. Time for a European initiative for research to prevent cancer: A manifesto $\mathrm{T}$ for Cancer Prevention Europe (CPE). J Cancer Policy 2018; 17: 15-23.

16. Munro AJ. Comparative cancer survival in European countries. Br Med Bull 2014; 110 (1): 5-22.

17. Vrdoljak E, Bodoky G, Jassem J, et al. Cancer Control in Central and Eastern Europe: Current Situation and Recommendations for Improvement. Oncologist 2016; 21 (10): 1183-1190.

18. Luengo-Fernandez R, Leal J, Gray A, Sullivan R. Economic burden of cancer across the European Union: a population-based cost analysis. Lancet Oncol 2013; 14 (12): 1165-1174.

19. Ades F, Senterre C, de Azambuja E, et al. Discrepancies in cancer incidence and mortality and its relationship to health expenditure in the 27 European Union member states. Ann Oncol 2013; 24 (11): 2897-2902.

20. Grau C, Defourny N, Malicki J, et al. Radiotherapy equipment and departments in the European countries: Final results from the ESTRO-HERO survey. Radiother Oncol 2014; 112 (2): 155164.

21. Borras, JM, Lievens, Y, Dunscombe, P, et al. The optimal utilization proportion of external beam radiotherapy in European countries: An Estro-Hero analysis. Radiother Oncol 2015; 116 (1): 38-44.

22. Borras JM, Lievens Y, Barton M, et al. How many new cancer patients in Europe will require radiotherapy by 2025? An ESTRO-HERO analysis. Radiother Oncol 2016; 119 (1): 5-11.

23. Gatta G, Trama A, Capocaccia R. Variations in cancer survival and patterns of care across Europe: roles of wealth and healthcare organization. J Natl Cancer Inst Monogr 2013; 2013 (46): 79-87.

24. Ades F, Zardavas D, Senterre C, et al. Hurdles and delays in access to anti-cancer drugs in Europe. Ecancermedicalscience 2014; 8: 482

25. Tambor M, Pavlova M, Rechel B, et al. The inability to pay for health services in Central and Eastern Europe: evidence from six countries. Eur J Public Health 2014; 24 (3): 378-385.

26. Cherny N, Sullivan R, Torode J, et al. ESMO European Consortium Study on the availability, out-of-pocket costs and accessibility of antineoplastic medicines in Europe. Ann Oncol 2016; 27 (8): 1423-1443.

27. OECDiLibrary. Health at a Glance: Europe 2018: State of Health in the EU Cycle. Available from: https://www.oecd-ilibrary.org/social-issues-migration-health/health-at-a-glanceeurope-2018_health_glance_eur-2018-en (accessed: 11 June 2020). 
28. Osmani L, Askin F, Gabrielson E, Li QK. Current WHO guidelines and the critical role of immunohistochemical markers in the subclassification of non-small cell lung carcinoma (NSCLC): Moving from targeted therapy to immunotherapy. Semin Cancer Biol 2018; 52 (Pt 1): 103-109.

29. Laing GM, Chapman AD, Smart LM, Kerr KM. Histological diagnosis: recent developments. In: Dingemans A-MC, Reck M, Westeel (Eds). ERS Monograph: Lung Cancer. European Respiratory Society; 2015: 64-78.

30. Ryska A, Buiga R, Fakirova A, et al. Non-Small Cell Lung Cancer in Countries of Central and Southeastern Europe: Diagnostic Procedures and Treatment Reimbursement Surveyed by the Central European Cooperative Oncology Group. Oncologist 2018; 23 (12): e152-e158.

31. Brcic L, Cufer T, Ryska A, et al. Availability and reimbursement of diagnostic testing and novel anti-cancer drugs for NSCLC in CEE: results of a CECOG survey. Poster No. P2.15-03. J Thorac Oncol 2018; 13 (10): 818.

32. Howard DH, Bach PB, Berndt ER, Conti RM. Pricing in the Market for Anticancer Drugs. J Econ Perspect 2015; 29 (1): 139-162.

33. Ades F, Senterre C, Zardavas D, et al. An exploratory analysis of the factors leading to delays in cancer drug reimbursement in the European Union: the trastuzumab case. Eur J Cancer 2014; 50 (18): 3089-3097.

34. Ades F, Senterre C, Zardavas D, et al. Are life-saving anticancer drugs reaching all patients? Patterns and discrepancies of trastuzumab use in the European Union and the USA. PLoS One 2017; 12 (3): e0172351.

35. Miljkovic N, Gibbons N, Batista A, et al. Results of EAHP's 2018 Survey on Medicines Shortages. Eur J Hosp Pharm 2018; 26: 60-65.

36. Santos SB, Sousa Lobo JM, Silva AC. Biosimilar medicines used for cancer therapy in Europe: a review. Drug Discov Today 2019; 24 (1): 293-299.

37. OECD Health Policy Studies. Value for Money in Health Spending. Available from:http://www.oecd.org/els/health-systems/value-for-money-in-health-spending.htm (accessed: 11 June 2020).

38. OECD Health Policy Studies. Pharmaceutical Innovation and Access to Medicines. Available from: https://www.oecd. org/health/pharmaceutical-innovation-and-access-to-medicines-9789264307391-en.htm (accessed: 11 June 2020).

39. Vogler S, Österle A, Mayer S. Inequalities in medicine use in Central Eastern Europe: an empirical investigation of socioeconomic determinants in eight countries. Int J Equity Health 2015; 14: 124

40. Delaney G, Jacob S, Featherstone C, Barton M. The role of radiotherapy in cancer treatment: estimating optimal utilization from a review of evidence-based clinical guidelines. Cancer 2005; 104 (6): 1129-1137.

41. Slotman BJ, Cottier B, Bentzen SM, et al. Overview of national guidelines for infrastructure and staffing of radiotherapy. ESTRO-QUARTS: work package 1. Radiother Oncol 2005; 75 (3): 349-354.

42. IAEA, 2010. International Atomic Energy Agency. IAEA Human Health Series Nos. 14. Planning national radiotherapy services: a practical tool. Available from: https://www-pub.iaea.org/
MTCD/Publications/PDF/Pub1462_web.pdf (accessed: 11 June 2020).

43. Rosenblatt E, Izewska J, Anacak Y, Pynda Y, et al. Radiotherapy capacity in European countries: an analysis of the Directory of Radiotherapy Centres (DIRAC) database. Lancet Oncol 2013; 14 (2): e79-86

44. Lievens Y, Dunscombe P, Defourny N, et al. HERO (Health Economics in Radiation Oncology): a pan-European project on radiotherapy resources and needs. Clin Oncol (R Coll Radiol) 2015; 27 (2): 115-124.

45. Datta NR, Samiei M, Bodis S. Radiotherapy infrastructure and human resources in Europe - present status and its implications for 2020. Eur J Cancer 2014; 50 (15): 2735-2743.

46. Romero Y, Trapani D, Johnson S, et al. National cancer control plans: a global analysis. Lancet Oncol 2018; 19 (10): e546-e555.

47. Benstead K, Turhal NS, O'Higgins N, et al. Multidisciplinary training of cancer specialists in Europe Eur J Cancer 2017; 83: 1-8.

48. Mons U, Gredner T, Behrens G, et al. Cancers due to smoking and high alcohol consumption. Dtsch Arztebl Int 2018; 115:571-577. Behrens G, Gredner T, Stock C, et al. Cancers due to excess weight, low physical activity, and unhealthy diet. Dtsch Arztebl Int 2018; 115:578-585.

49. Islami F, Goding Sauer A, Miller KD, et al. Proportion and number of cancer cases and deaths attributable to potentially modifiable risk factors in the United States. CA Cancer J Clin 2018; 68 (1): 31-54.

50. Brown KF, Rumgay H, Dunlop C, et al. The fraction of cancer attributable to modifiable risk factors in England, Wales, Scotland, Northern Ireland, and the United Kingdom in 2015. Br J Cancer 2018; 118: 1130-1141.

51. Gredner T, Behrens G, Stock C, et al. Cancers due to infection and selected environmental factors. Dtsch Arztebl Int 2018; 115 (35-36): 586-593.

52. Cancer control: prevention. WHO Guide for effective programmes. Available from: https://www.who.int/cancer/publications/cancer_control_prevention/en/ (accessed: 11 June 2020).

53. WHO, 2013. Global Action Plan for the Prevention and Control of Noncommunicable Diseases 2013-2020. Geneva: World Health Organization; 2013. Available from: https://www.who. int/nmh/events/ncd_action_plan/en/ (accessed: 11 June 2020).

54. Action Plan for the Prevention and Control of Noncommunicable Diseases in the WHO European Region 2016-2025. Available from: https://www.euro.who.int/en/health-topics/noncommunicable-diseases/pages/policy/publications/ action-plan-for-the-prevention-and-control-of-noncommunicable-diseases-in-the-who-european-region-20162025 (accessed: 11 June 2020).

55. Schüz J, Espina C, Villain P, et al. Working Groups of Scientific Experts. European Code against Cancer $4^{\text {th }}$ Edition: 12 ways to reduce your cancer risk. Cancer Epidemiol 2015; 39 (Suppl 1): S1-10.

56. Lauby-Secretan B, Scoccianti C, Loomis D, et al; Breast-cancer screening--viewpoint of the IARC Working Group. N Engl J Med 2015; 372 (24): 2353-2358.

57. Basu P, Ponti A, Anttila A, et al. Status of implementation and organization of cancer screening in The European Union Mem- 
ber States-Summary results from the second European screening report. Int J Cancer 2018; 142: 44-56.

58. von Karsa L, Anttila A, Ronco G, et al. Cancer screening in the European Union. Report on the implementation of the Council Recommendation on cancer screening. First report. Brussels: European Commission; 2008. Available from: https:// ec.europa.eu/health/sites/health/files/major_chronic_diseases/docs/2017_cancerscreening_2ndreportimplementation_ en.pdf (accessed: 11 June 2020).

59. Oudkerk M, Devaraj A, Vliegenthart R, et al. European position statement on lung cancer screening. Lancet Oncol 2017; 18 (12): e754-e766

60. Pedersen JH, Sørensen JB, Saghir Z, et al. Implementation of lung cancer CT screening in the Nordic countries. Acta Oncol 2017; 56 (10): 1249-1257

61. Frauenfelder T, Puhan MA, Lazor R, et al. Early detection of lung cancer: a statement from an expert panel of the Swiss university hospitals on lung cancer screening. Respiration 2014; 87 (3): 254-264.

62. Rzyman W, Didkowska J, Dziedzic R, et al. Consensus statement on a screening programme for the detection of early lung cancer in Poland. Adv Respir Med 2018; 86 (1): 53-74.

63. Vokó Z, Barra M, Molnár A, et al. Model concept of the health economic evaluation of low-dose CT lung cancer screening in Hungary Orv Hetil 2017; 158 (25): 963-975.

64. Anttila A, Lönnberg S, Ponti A, et al. Towards better implementation of cancer screening in Europe through improved monitoring and evaluation and greater engagement of cancer registries. Eur J Cancer 2015; 51 (2): 241-251.

65. Pukkala E, Engholm G, Højsgaard Schmidt LK, et al. Nordic Cancer Registries - an overview of their procedures and data comparability. Acta Oncol 2018; 57 (4): 440-455.

66. Zadnik V, Primic Zakelj M, Lokar K, et al. Cancer burden in Slovenia with the time trends analysis. Radiol Oncol 2017; 51 (1): 47-55.

67. Forsea AM. Cancer registries in Europe-going forward is the only option. Ecancermedicalscience 2016; 10: 641.

68. Siesling S, Louwman WJ, Kwast A, et al. Uses of cancer registries for public health and clinical research in Europe: Results of the European Network of Cancer Registries survey among 161 population-based cancer registries during 2010-2012. Eur J Cancer 2015; 51 (9): 1039-1049.

69. Coebergh JW, van den Hurk C, Rosso S, et al. EUROCOURSE recipe for cancer surveillance by visible population-based cancer RegisTrees in Europe: From roots to fruits. Eur J Cancer 2015; 51 (9): 1050-1063.

70. Zanetti R, Sacchetto L, Coebergh JW, Rosso S. To accelerate cancer prevention in Europe: Challenges for cancer registries. Eur J Cancer 2018; 104: 151-159.

71. Boyle P, Autier P, Bartelink H, et al. European Code Against Cancer and scientific justification: third version (2003). Ann Oncol 2003; 14 (7): 973-1005.

72. Armaroli P, Villain P, Suonio E, et al. European Code against Cancer, 4th Edition: Cancer screening. Cancer Epidemiol 2015; 39 (Suppl 1): S139-152.

73. Popescu RA, Schäfer R, Califano R, et al. The current and future role of the medical oncologist in the professional care for cancer patients: a position paper by the European Society for Medical Oncology (ESMO). Ann Oncol 2014; 25 (1): 9-15.

74. Dittrich C, Negrouk A, Casali PG; et al. An ESMO-EORTC position paper on the EU clinical trials regulation and EMA's transparency policy: making European research more competitive again. Ann Oncol 2015; 26 (5): 829-832.

75. Action Plan for Implementation of the European Strategy for the Prevention and Control of Noncommunicable Diseases 2012-2016. Available from: http://www.euro.who.int/en/ health-topics/noncommunicable-diseases/cancer/publications/2012/action-plan-for-implementation-of-the-european-strategy-for-the-prevention-and-control-of-noncommunicable-diseases-20122016 (accessed: 11 June 2020).

76. Challenges and opportunities in improving access to medicines through efficient public procurement in the WHO European Region. Available from: http://www.euro.who.int/_data/ assets/pdf_file/0003/323598/Challenges-opportunities-improving-access-medicines-efficient-public-procurement. pdf?ua=1 (accessed: 11 June 2020).

77. Aapro M, Astier A, Audisio R, et al. Identifying critical steps towards improved access to innovation in cancer care: a European CanCer Organisation position paper. Eur J Cancer 2017; 82: 193-202.

78. Borras JM, Albreht T, Audisio R, et al. Policy statement on multidisciplinary cancer care. Eur J Cancer 2014; 50 (3): 475480.

79. ECPC, 2017. European Cancer Patient Coalition Multi-annual Strategy 2017-2019. Brussels, 2017. Available from: http://www. ecpc.org/ECPC_Strategy_2016_2019.pdf (accessed: 11 June 2020).

80. de Lorenzo F, Apostolidis K. The European Cancer Patient Coalition and its central role in connecting stakeholders to advance patient-centric solutions in the mission on cancer. Mol Oncol 2019; 13 (3): 653-666.

81. LuCE, 2019. Lung Cancer Europe. Available from: https://www. lungcancereurope.eu (accessed: 11 June 2020).

82. LuCE, 2015. Lung Cancer Europe (LuCE) Posistion Paper 2015. Available from: https://www.lungcancereurope.eu/wp-content/ uploads/2017/10/LuCE-EU-Policy-Position-Paper-2015-IMPAGINATO.pdf (accessed: 11 June 2020).

83. Wait S, Han D, Muthu V, et al. Towards sustainable cancer care: Reducing inefficiencies, improving outcomes-A policy report from the All. Can initiative. J Cancer Policy 2017; 13: 47-64.

84. Rosenblatt E, Zubizarreta E, Wondergem J, et al. The International Atomic Energy Agency (IAEA): an active role in the global fight against cancer. Radiother Oncol 2012; 104: 269-271.

85. IAEA, 2019. International Atomic Energy Agency. All active CRPs. Available from: http://cra.iaea.org/cra/explore-crps/allactive-by-programme.html (accessed: 11 June 2020).

86. Esiashvili N. Radiation Oncology in the Developing Economies of Central and Eastern Europe. Semin Radiat Oncol 2017; 27 (2): 150-157.

87. Kivistik S. Case report: The Estonian experience of the IAEA/ ESTRO “Train the Trainers" project. Technical Innovations \& Patient Support in Radiation Oncology 2018; 8: 13-14.

88. Coffey M, Rosenblatt E, Vandevelde C, et al. A review of the Best Practice in Radiation Oncology project from 2008 to 2018. 
Technical Innovations \& Patient Support in Radiation Oncology 2018; 8: 3-7.

89. National cancer control programmes: policies and managerial guidelines. Available from: https://apps.who.int/iris/bitstream/ handle $/ 10665 / 37815 / 9241544740$. pdf;jsessionid=F876CBC39FB9D449D071F645022DC709? sequence= 1 (accessed: 11 June 2020).

90. National cancer control programmes: policies and managerial guidelines. $2^{\text {nd }}$ ed. Available from: https://www.who.int/cancer/ media/en/408.pdf (accessed: 11 June 2020).

91. Albreht T, Kiasuwa R, Van den Bulcke M. European Guide on Quality Improvement in Comprehensive Cancer Control National Institute of Public Health; Brussels: Scientific Institute of Public Health, 2017. Available from: https://cancercontrol. eu/archived/uploads/images/Guide/pdf/CanCon_Guide_ FINAL_Web.pdf (accessed: 11 June 2020).

92. Abdel-Wahab M, Lahoupe B, Polo A, et al. Assessment of cancer control capacity and readiness: the role of the International Atomic Energy Agency. Lancet Oncol 2017; 18 (10): e587-e594.

93. Richards MA. The size of the prize for earlier diagnosis of cancer in England. Br J Cancer 209; 101: S125-S129.

94. Di Girolamo C, Walters S, Gildea C, et al. Can we assess Cancer Waiting Time targets with cancer survival? A population-based study of individually linked data from the National Cancer Waiting Times monitoring dataset in England, 2009-2013. PLoS One 2018; 13 (8): e0201288.

95. Zhou Y, Mendonca SC, Abel GA, et al. Variation in 'fast-track' referrals for suspected cancer by patient characteristic and cancer diagnosis: evidence from 670000 patients with cancers of 35 different sites. Br J Cancer 2018; 118 (1): 24-31.

96. Fuller E, Fitzgerald K, Hiom S. Accelerate, Coordinate, Evaluate Programme: a new approach to cancer diagnosis. Br J Gen Pract 2016; 66 (645): 176-177.

97. Wilkens J, Thulesius H, Schmidt I, Carlsson C. The 2015 National Cancer Program in Sweden: Introducing standardized care pathways in a decentralized system. Health Policy 2016; 120 (12): 1378-1382.

98. Probst HB, Hussain ZB, Andersen O. Cancer patient pathways in Denmark as a joint effort between bureaucrats, health professionals and politicians-A national Danish project. Health Policy 2012; 105 (1): 65-70.

99. Vedsted P, Olesen F. A differentiated approach to referrals from general practice to support early cancer diagnosis - the Danish three-legged strategy. Br J Cancer 2015; 112 (Suppl 1): S65-S69.

100. Pitter JG, Csanádi M, Szigeti A, et al. Planning, implementation and operation of a personalized patient management system for subjects with first suspect of cancer (OnkoNetwork): system description based on a qualitative study. BMC Health Serv Res 2019; 19 (1): 131.

101. Banzi R, Gerardi C, Bertele V, Garattini S. Approvals of drugs with uncertain benefit-risk profiles in Europe. Eur J Intern Med 2015; 26 (8): 572-584

102. Kim C, Prasad V. Cancer Drugs Approved on the Basis of a Surrogate End Point and Subsequent Overall Survival: An Analysis of 5 Years of US Food and Drug Administration Approvals. JAMA Intern Med 2015; 175 (12): 1992-1994.
103. Grössmann N, Robausch M, Rosian K, et al. Monitoring evidence on overall survival benefits of anticancer drugs approved by the European Medicines Agency between 2009 and 2015. Eur J Cancer 2019; 110: 1-7.

104. ATU, authorisation temporaire d' utilisation. Available from: http:// www.icta.fr/expertise/atu-and-rtu.aspx (accessed: 11 June 2020).

105. Cancer drugs fund. Available from: https://www.england.nhs. uk/cancer/cdf/. (accessed: 11 June 2020).

106. Van Dyck W, Schoonaert L. Acting with Foresight in Times of Budget Austerity, Vlerick Policy Paper \#9. Available from: https://www.vlerick.com/ /media/Corporate/Pdf-knowledge/ Vlerick-Policy-Paper-Acting-With-Foresight-In-Times-OfBuget-Austeritypdf.pdf (accessed: 11 June 2020).

107. Cherny NI, Sullivan R, Dafni U, et al. A standardised, generic, validated approach to stratify the magnitude of clinical benefit that can be anticipated from anti-cancer therapies: the European Society for Medical Oncology Magnitude of Clinical Benefit Scale (ESMO-MCBS). Ann Oncol 2015; 26 (8): 1547-1573.

108. Cherny NI, Dafni U, Bogaerts J, et al. ESMO-Magnitude of Clinical Benefit Scale version 1.1. Ann Oncol 2017; 28 (10): 2340-2366.

109. Ferrario A, Humbert T, Kanavos P, Pedersen HB. Strategic procurement and international collaboration to improve access to medicines. Bull World Health Organ 2017; 95 (10): 720-722.

110. Vogler S, Paris V, Ferrario A, et al. How Can Pricing and Reimbursement Policies Improve Affordable Access to Medicines? Lessons Learned from European Countries. Appl Health Econ Health Policy 2017; 15 (3): 307-321.

111. OECD. New Health Technologies. Managing Access, Value and Sustainability. Published on January 15, 2017. Available from: http://www.oecd.org/health/managing-new-technologies-in-health-care-9789264266438-en.htm (accessed: 11 June 2020).

112. Espín J, Rovira J, Calleja A. How can voluntary cross-border collaboration in public procurement improve access to health technologies in Europe? Policy Brief 21. European Observatory on Health Systems and Policies;2016. Available from: http:// www.euro.who.int/_data/assets/pdf_file/0009/331992/PB21. pdf (accessed: 11 June 2020).

113. Danzon PM, Towse A. Differential pricing for pharmaceuticals: reconciling access, $R \& D$ and patents. Int J Health Care Finance Econ 2003; 3 (3): 183-205.

114. Policy Principles on Cross-country Collaborations on Medicines' Pricing and Access EFPIA, 2019: Available from: https://efpia.eu/news-events/the-efpia-view/blog-articles/ policy-principles-on-cross-country-collaborations-on-medicines-pricing-and-access (accessed: 11 June 2020).

115. Achour L, Chachoua L, Hanna E, et al. European Experiences of Cross-Border Collaboration in Procurement of Health Technologies. Value Health 2018; 21 (2): S49.

116. Garrison LP Jr, Towse A, Briggs A, et al. Performance-based risk-sharing arrangements-good practices for design, implementation, and evaluation: report of the ISPOR good practices for performance-based risk-sharing arrangements task force. Value Health 2013; 16 (5): 703-719. 
117. Ferrario A, Kanavos P. Dealing with uncertainty and high prices of new medicines: a comparative analysis of the use of managed entry agreements in Belgium, England, the Netherlands and Sweden. Soc Sci Med 2015; 124: 39-47.

118. Sim D. Linking cancer drug prices to treatment success could speed up approvals. But what do patients consider success? Available from: https://scienceblog.cancerresearchuk. org/2019/02/21/linking-cancer-drug-prices-to-treatment-success-could-speed-up-approvals-but-what-do-patients-consider-success (accessed: 11 June 2020).

\section{AUTHORS' CONTRIBUTIONS}

$C T, I B, A C, T C, J J, B K, L E M, B P, R R, R S, N W$ and $C Z$ generated data and made the analyzes of the data, $C T, T C, J$ J, RO, AR, NW and CZ worked on the concept and design of the publication, CT, AR and CZ wrote and revised the publication. All authors have given their final approval to the final version of the paper. 


\section{SUPPLEMENTARY MATERIAL}

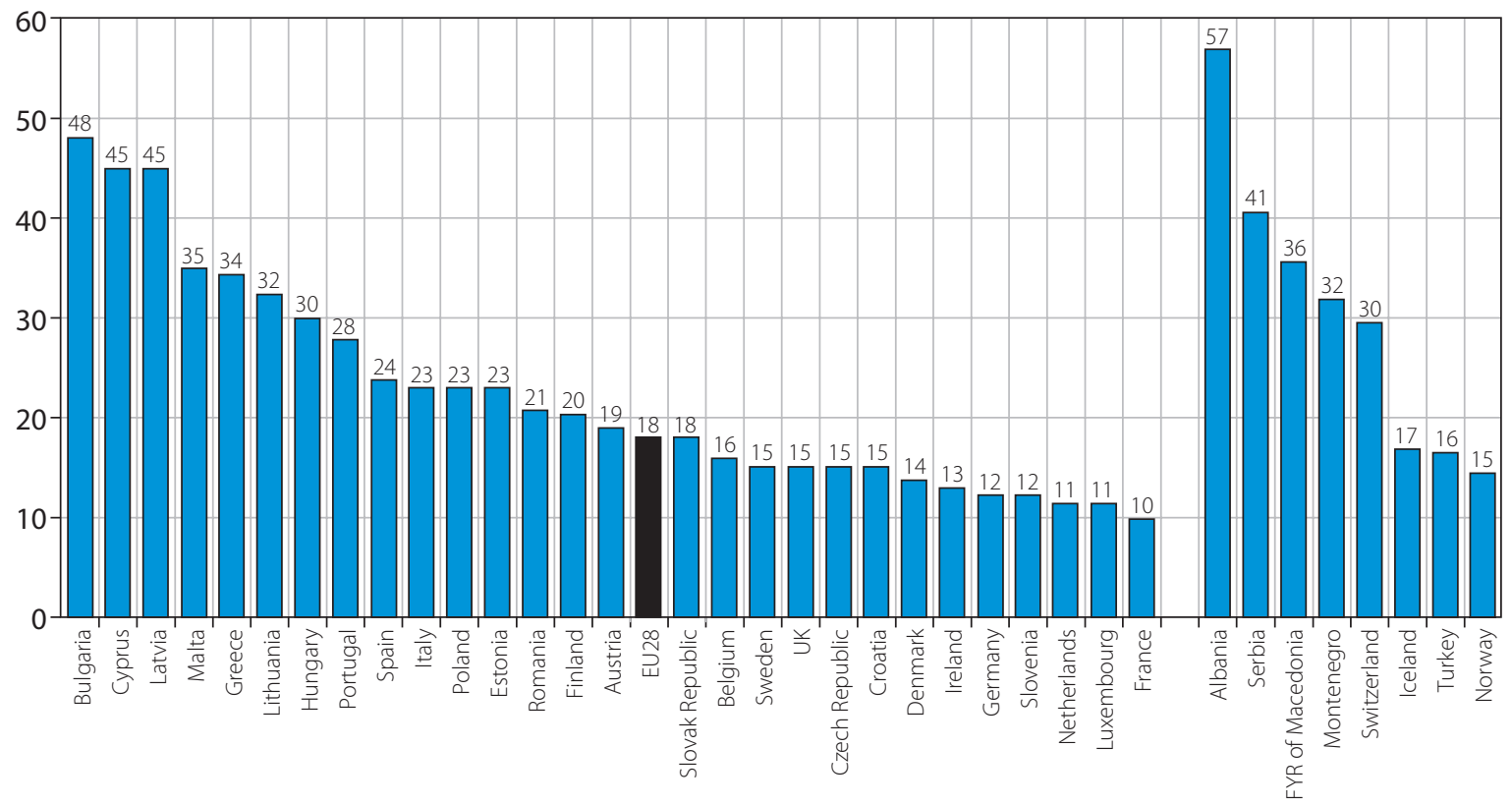

FIG. S1. Out-of-pocket payments for health services (\% of current health expenditure) in Europe in 2016 (or latest year) [25]. Statlink: http://dx.doi.org/10.1787/888933836276

TABLE S1. Initiatives by the European Union

\begin{tabular}{|l|l|l|}
\hline Acronym & Initiative & Aims \\
\hline EAC & Europe against Cancer & $\begin{array}{l}\text { To accelerate primary prevention, health promotion, } \\
\text { education for the public and health professionals } \\
\text { and scientific research }\end{array}$ \\
\hline CANCON & $\begin{array}{l}\text { European Partnership for Action Against } \\
\text { Cancer }\end{array}$ & $\begin{array}{l}\text { To bring together the efforts of different stakeholders } \\
\text { into a joint response to prevent and control cancer }\end{array}$ \\
\hline JARC & $\begin{array}{l}\text { Joint Action on Rare Cancers } \\
\text { iPAAC }\end{array}$ & $\begin{array}{l}\text { To contribute in different ways to reducing the cancer } \\
\text { burden in the EU by creating a European Guide on } \\
\text { Quality Improvement in Comprehensive Cancer Control }\end{array}$ \\
\hline Cancer & $\begin{array}{l}\text { Europer } \text { advance quality of care and research on rare } \\
\text { cancers }\end{array}$ \\
\hline ECIBC & Euncer & $\begin{array}{l}\text { To implement innovative approaches to cancer } \\
\text { control, e.g. Work Package 7 to enhance population- } \\
\text { based cancer information systems to better support } \\
\text { evidence-based comprehensive cancer care }\end{array}$ \\
\hline ENCR & $\begin{array}{l}\text { European Cancer Information System } \\
\text { ECIS }\end{array}$ & $\begin{array}{l}\text { To improve breast cancer care and develop evidence } \\
\text {-based recommendations on screening and diagnosis }\end{array}$ \\
\hline
\end{tabular}

Source: The authors from publicly available European Commission reports and data 